\section{Naval Research and Development}

DR. C. F. Goodeve, the first holder of the post of deputy controller for research and development in the Admiralty, has left the department to take up the directorship of the British Iron and Steel Research Association. The post of assistant controller for research and development was instituted in 1942 and the status of the post has since been raised to that of deputy controller. The holder not only helps the controller of the Navy in supervising the application of science, technology and design engineering in the large range of departments which work under his superintendence, but is also adviser to the Board on research and development generally. Before Dr. Goodeve was appointed to this post he had been for some time previously associated with the Admiralty as an R.N.V.R. officer.

The new deputy controller for research and development is Mr. A. P. Rowe, who has during the War been head of the largest radar research establishment in Britain, the telecommunications research establishment at Malvern. This establishment, under the Minister of Aircraft Production, has been responsible for the research and design of the radar equipment both of the R.A.F. and the Fleet Air Arm. Mr. Rowe's connexions with defence research work go back to 1922, when he first joined the scientific staff of the Air Ministry.

\section{Terrestrial Magnetism and Atmospheric Electricity}

THE present year, 1945, will mark the completion of the fiftieth year of the quarterly publication, Terrestrial Magnetism and Atmospheric Electricity, the foundation of which by L. A. Bauer in 1896 was a step of far-reaching importance for the progress of the sciences named in its title. It provides a most valuable focus and forum for them, and for border subjects related to them, such as sunspot and ionospheric studies. Though the editorial and financial responsibility for the periodical has always been American, in the hands of its two successive editors, L. A. Bauer (1896-1932) and J. A. Fleming (1928 to date), the periodical is international in the sense that foreign associates have been and are linked with the responsible editors, and can advise or make suggestions either when requested or on their own initiative; and also that suitable contributions from all countries have been welcomed and have provided a considerable share of the matter printed. Moreover, though most of the papers are printed in English, and always have been, papers are invited also in French, German and Italian. The pages of the fifty volumes well mirror the great progress that has been made in these branches of geophysics during the halfcentury, and the printing and production have been maintained at a high standard from the outset, and throughout the war years. The subscription-rate, 3.50 dollars per year, is less than double that of 1896 , and is remarkably low for a periodical of its size and excellence. The best wishes of the Editors and of many of the readers of Nature will be with the direction of Terrestrial Magnetism as it begins its second half-century next year.

\section{Science and Development in Australia}

The John Murtagh Macrossan Memorial Lectures delivered to the University of Queensland by Sir David Rivett on June 13 and 15, 1944, on "The Application of Science to Industry in Australia", have now been published (Brisbane: University of Queensland. Pp. 48). Sir David, while emphasiz- ing the importance of the international exchange of ideas and thought and of traffic in the products of the experimental laboratory and of the original mind, points out that some decrease in the international to-and-fro movements of products of soil and factory, and in particular a diminished demand overseas for Australian primary products, may be expected, and may even be desirable, to eliminate unnecessary transport. Distribution, he suggested, has become once more a main factor in Australian economy ; if we look after consumption, both in quality and in quantity, production will look after itself. That involves basing industrial life on the best human knowledge that is available or ascertainable; and if industrial activity in Australia is to be much more diversified, some general ideas as to the main linos of development and the place of scientific effort in that development are essential. We must think in advance so far as possible in a democracy; but we should do so with the clear understanding that the divergent phenomena of which all plans concerned with human relations have to take account make most plans nothing more than intelligent guesses as to the best justifiable and possible courses. As such they should, like any other hypothesis of the sciontific worker, be discarded or amended when the facts prove such treatment to be necessary.

With regard to primary resources, Sir David Rivett believes that Australia should find more consumers within her own borders, these consumers making other products required in return. The building up of secondary industries is imperative, and Sir David referred particularly to shipbuilding and the aircraft industry, light metals and alloy steels for these and other transport purposes, including the motor-car industry, the manufacture of goods for the electrical industry, building materials, household accessories, organic chemicals from alcohol, coal and carbide, engineering, the prepared food industry and mineral industries from the raw material to the finished product. Not more than 200,000 out of every million people would be required to supply that million with foodstuffs and clothing by Australian standards, and the remaining 800,000 should be absorbed in such secondary industries. Such development will only be possible if the universities of Australia are adequately developed and take their full place in fundamental research. National laboratories will be required for such work; but science must not be regarded as just the handmaid of industry. Industry should attend to its own scientific housekeeping, and the national laboratories and the universities should be given the utmost freedom to prosecute fundamental research. Urging the importance of education as a factor in industrial development, he referred finally to the problem of the impact of society upon science: the outstanding problem, he believes, is the handling of our present and coming powers so that their enormous possibilities for the good of humanity will be realized and applied to the total exclusion of any deliberate pursuit of evil aims.

\section{Scientific Rehabilitation in Europe}

Prof. G. I. Finch, professor of applied physical chemistry in the Imperial College of Science and Technology, is visiting Belgium and Holland to convey the greetings of the Royal Society on behalf of the men of science of Great Britain to their colleagues in those countries. The purpose of his visit is to renew and re-establish scientific contacts and to see what help can be given by British science towards the 